\title{
Removal of Arsenic from Drinking Water by Hydroxyapatite Nanoparticles
}

\author{
MAHSA MIRHOSSEINI ${ }^{*}$, ESMAEIL BIAZAR ${ }^{1}$ and KEIVAN SAEB ${ }^{2}$ \\ *Department of Environment, Tonekabon Branch, Islamic Azad University, Tonekabon, Iran. \\ ${ }^{1}$ Department of Engineering Sciences, Tonekabon Branch, Islamic Azad University, Tonekabon, Iran \\ ${ }^{2}$ Department of Environment, Tonekabon Branch, Islamic Azad University, Tonekabon, Iran.
}

http://dx.doi.org/10.12944/CWE.9.2.13

(Received: January 24, 2014; Accepted: June 09, 2014)

\begin{abstract}
Arsenic(As) contained in drinking water can cause adverse effects on human health. This study investigated the effect of hydroxyapatite nanoparticles (nano-HAp) on sorption of $A s(V)$ ions in aqueous solution. The amounts of arsenic ion,nano-HAp and $\mathrm{pH}$ on removal efficiency were also investigated. Results showed that the removal of arsenate from water using hydroxyapatite nanoparticles, improved with increasing $\mathrm{pH}$. The optimum amount of nano-HAp for As (V) removal is found to be $0 / 6 \mathrm{~g} / \mathrm{L}$ with the removal efficiency of $88 \%$. The sorption data were then correlated with the Langmuir, Freundlich, adsorption isotherm models. The results indicated that nano-HAp can be used as an effective adsorbent for removal of $\mathrm{As}(\mathrm{V})$ from aqueous solution.
\end{abstract}

Key words:Arsenic, Water filtration, Hydroxyapatite nano particles, Adsorption, pH.

\section{INTRODUCTION}

Arsenic compounds are common contaminants in the environment. Because of arsenic toxicity and induced carcinogenetic agents (Eblin et al., 2006; Hughes.,2002), higher arsenic concentration in the environment represents serious problems for human health, especially for populations in Bangladesh, Western Bengal, Vietnam,China, Mexico and Chile. The danger of elevated arsenic concentration in waters in these countries was under lined by $\mathrm{WHO}$, which estimated the recommended limit for arsenic concentration in drinking waters up to $10 \mu \mathrm{g} / \mathrm{L}$ Arsenic-contaminated drinking water can cause adverse health effects in human beings. Arsenic plays crucial role in making disturbance in RNA and DNA synthesis, which consequently lead to cancer. Increasing birth of exceptional child, low birth weight, malformed child and dead births were reported due to Arsenic compounds (Jain et al., 2000; Kiping et al.,1997; $\mathrm{Ng}$ et al.,2001; Bissen et al.,2003; Penrose et al.,2009; Ng et al.,2003; Burkel et al.,1999; Smedley et al.,2002). The conventional technologies for arsenic removal from waters are based on processes of coagulation, sorption, ionexchange reactions or methods of reverse osmosis. Materials used in these processes are $\mathrm{Fe}^{0}, \mathrm{Fe}$ (III) oxyhydroxides, $\mathrm{Mn}$ (II), Al(III), apatite, silicate sands, carbonates, sulphides, ashor various types of coal (Chmielewská et al.,2008; Daus et al.,2004; DeMarco et al.,2003; Hiller et al.,2007; Lin et al.,2001; Sato et al.,2002; Song et al.,2006). Now a days, there is a trend to use the alternative and low-cost materials for arsenic removal from the waters in laboratory or medium-scale experiments, too. Effectiveness of chemically modified or native biomass in processes of arsenic removal was evaluated and proved by various authors (Abdel-Ghani et al.,2007; Boddu et al.,2008; Cernansky et al.,2007; Loukidou et al.,2003; Malakootian et al.,2009; Murugesan et al.,2006; Rahaman et al.,2008; Seki et al.,2005). Calcium hydroxyapatite $(\mathrm{HAp}), \mathrm{Ca}_{10}\left(\mathrm{PO}_{4}\right)_{6}(\mathrm{OH})_{2}$, has also been used for the removal of heavy metals from contaminated soils, waste water and fly ashes (Omar et al.,2003; Takeuchi et al.,1990).Calcium hydroxyapatite (Ca-HAp) is a principal component 
of hard tissues and has been of interest in industry and medical fields. Its synthetic particles find many applications in bioceramics, chromatographic adsorbents to separate protein and enzyme, catalysts for dehydration and dehydrogenation of alcohols, methane oxidation, and powders for artificial teeth and bones paste germicides (Elliott et al.,1994). These properties relate to various surface characteristics of HAp, e.g., surface functional groups, acidity and alkaline, surface charge, hydrophilicity, and porosity. It has been found that Ca-HAP surface with to $\mathrm{P}-\mathrm{OH}$ groups acting as sorption sites (Tanaka et al., 2005). The sorption properties of HAp are of great importance for both environmental processes and industrial purposes. Hydroxyapatite is an ideal material for long-term containment of contaminants because of its high sorption capacity for actinides and heavy metals, low water solubility, high stability under reducing and oxidizing conditions, availability, and low cost(Krestou et al.,2004). HAP has been utilized in the stabilization of a wide variety of metals (e.g., $\mathrm{Cr}, \mathrm{Co}, \mathrm{Cu}, \mathrm{Cd}, \mathrm{Zn}, \mathrm{Ni}, \mathrm{Pu}, \mathrm{Pb}, \mathrm{As}, \mathrm{Sb}, \mathrm{U}$, and V) by many investigators (Omar et al.,2003; Ramesh et al.,2012; Vega et al.,1999). They have reported the sorption is taking place through ionic exchange reaction, surface complex with phosphate, calcium and hydroxyl groups and/or co-precipitation of new partiallysoluble phases. In this study, the effect of Hap nanoparticles on removal efficiency of arsenic ions in different conditions investigated.

\section{MATERIALS AND METHODS}

The hydroxyapatite nanoparticles previously have prepared (Montazeri and Biazar., 2011)and characterized by using the different analyses. The $\mathrm{pH}$ values of the solution were roughly adjusted from 2 to 12 by adding $\mathrm{HNO}_{3}$ and $\mathrm{NaOH}$ respectively. The $\mathrm{pH}$ of the solutions was then accurately noted. Hydroxyapatite nanoparticles with different concentrations were added to each flask and securely capped, immediately. The suspension was then manually agitated. The $\mathrm{pH}$ values of the supernatant liquid were noted.Metal salt of $\left(\mathrm{HAsNA}_{2} \mathrm{O}_{4} \cdot \mathrm{H}_{2} \mathrm{O}\right)$ was used to prepare metal ion $(\mathrm{As}(\mathrm{V}))$ solution. Sorption studies were carried out by shaking aseries of bottles containing different amounts of HAp-nano in $50 \mathrm{~mL}$ of metal ions solution with different concentrations and $\mathrm{pH}$. Suspensions were exposed toultrasonic waves (50W,20 min; ), to disperse nanopaticles. The samples were stirred at room temperature at 250 rpm for $1 \mathrm{~h}$ (Equilibrium time), then centrifuged for 5 min and the supernatant liquid was analyzed by an atomic absorption spectrometer(S-series, Thermo Scientific; USA).

\section{RESULTS AND DISCUSSION}

\section{Effect of $\mathrm{pH}$}

The $\mathrm{pH}$ is a significant factor for determining the form of the metallic species in aqueous media. It influences the adsorption process of metal ions, as it determines the magnitude and sign of the charge on ions (Gupta et al.,2005). The effect of solution $\mathrm{pH}$ on the sorption of $\mathrm{As}(\mathrm{V})$ ions from the aqueous solution by Hap-nanoin different concentrations was investigated in the $\mathrm{pH}$ range of 2-12 with the As $(\mathrm{V})$ concentrations of $0 / 6 \mathrm{~g} / \mathrm{L}$. The result is shown in Fig 1. It was found that the adsorption capacity of HAp increases with increase in $\mathrm{pH}$ in acidic

Table. 1: Comparison of contact time for As(V) removal

\begin{tabular}{|c|c|c|}
\hline No. Adsorbent & Equilibrium time & References \\
\hline $\begin{array}{l}\text { Activated } \\
\text { Aluminasupported iron } \\
\text { Oxid }\end{array}$ & $\begin{array}{l}4,8,12 \text { and } 36 \mathrm{~h} \text {, corresponding } \\
\text { to } \mathrm{Pb}(\mathrm{II}) \text { initial concentrations of } 0.1 \text {, } \\
0.2,0.4 \text { and } 0.8 \mathrm{mM} \text {, respectively }\end{array}$ & Huang et al. (2007) \\
\hline $\begin{array}{l}\text { Rice husk, maize cobs and } \\
\text { sawdust }\end{array}$ & $90 \mathrm{~min}$ & Abdel-Ghani et al. (2007) \\
\hline Syzygium cumini L. & $10 \mathrm{~min}$ & King et al. (2007) \\
\hline Bamboo dust carbon & $45 \mathrm{~min}$ & Kannan and Veemaraj (2009) \\
\hline Commercial activated carbon & $35 \mathrm{~min}$ & Kannan and Veemaraj (2009) \\
\hline Calcite & $10 \mathrm{~min}$ & Yavuz et al. (2007) \\
\hline $\mathrm{HA}$ & $60 \mathrm{~min}$ & Present study \\
\hline
\end{tabular}


medium. But in alkaline conditions, the removal efficiency remains constant, approximately. The effects of $\mathrm{pH}$ on arsenate removal by HAp-nano suggest that electrostatic attraction is not a major mechanism responsible for the arsenate sorption under our experimental conditions; otherwise the apparent arsenate sorption would decrease with increasing $\mathrm{pH}$. The sorbent dissolution can result in a decrease of sorbent mass and an increase of phosphate concentration in water, both of which can inhibit arsenate sorption. Lowering $\mathrm{pH}$ can favor the dissolution HAp-nano, and thus suppress arsenate sorption (Sneddon et al.,2005; Valsami-Jones et al.,1998; Mohan et al.,2007).

\section{Effect of Arsenic concentration}

For study the effect of solution arsenate amount on the sorption of $\mathrm{As}(\mathrm{V})$ ions from the aqueous solution by HAp-nanoin different concentrations was investigated in the range of $(0 / 1,0 / 2,0 / 4,0 / 6$ $\mathrm{g} / \mathrm{L}$ in $\mathrm{pH}: 8)$. The result is shown in fig 2 . increase arsenate absorption occurred with increasing arsenaterate. Arsenate adsorption, in different concentrations of arsenate in water, investigated in nano-hydroxyapatite, showed a similar increase approximately, As a result, absorption levels for these different amounts of arsenate are significant.

\section{Effect of contact time}

The time-dependent behavior of $\mathrm{As}(\mathrm{V})$ dsorption was measured by varying the contact time between adsorbate and adsorbent in the range of 5-120 min. The percentag adsorption of $\mathrm{As}(\mathrm{V})$ with different contact time is shown in Fig. 3. From Fig. 3, it can be observed that the rate of removal of $\mathrm{As}(\mathrm{V})$ ions was higher at the initial stage, due to the availability of more active sites on the surface of $\mathrm{HA}$ and became slower at the later stages of contact time, due to the decreased or lesser number of active sites (Kannan and Karrupasamy 1998). It is apparent from Fig. 3 that until $1 \mathrm{~h}$, the percentage removal of $\mathrm{As}(\mathrm{V})$ from aqueous solution increases rapidly and reaches up to $85 \%$. A further increase in contact time has a negligible effect on the percentage removal. Therefore, a $1 \mathrm{~h}$ shaking time was considered as equilibrium time for maximum adsorption. The decrease in rate of removal of $\mathrm{As}(\mathrm{V})$ with time may also be due to aggregation of $\mathrm{As}(\mathrm{V})$ around the HA particles. This aggregation may hinder the migration of adsorbate, as the adsorption sites become filled up, and also resistance to diffusion of As(V) molecules in the adsorbents increases(Mittal et al. 2010).

Table. 2: Isotherm parameters for sorption of $\mathrm{As}(\mathrm{V})$ by HA

\begin{tabular}{|c|c|c|c|c|c|}
\hline \multicolumn{3}{|c|}{ Langmuir isotherm constants } & \multicolumn{3}{|c|}{ Freundlich isotherm constants } \\
\hline$x q_{\max }$ & $\boldsymbol{b}$ & $r^{2}$ & $\bar{k}$ & $n$ & $r^{2}$ \\
\hline 526 & 0/053 & 0/938 & $6 / 683$ & 0/207 & 0/975 \\
\hline
\end{tabular}

Table. 3: Comparison of As (V)) adsorption capacities of different adsorbents

\begin{tabular}{lcc}
\hline Adsorbents & $\begin{array}{c}\text { Freundlich } \\
\text { parameters } \\
\mathbf{K}(\mathbf{m g} / \mathbf{g})\end{array}$ & $\begin{array}{c}\text { Author and the } \\
\text { source are credited } \\
\text { References }\end{array}$ \\
\hline Magnetiteemaghemite nanoparticles & 10.6 & 24 \\
TiO2 at pH 9 & 16 & 43 \\
Akaganeite & 69.7 & 44 \\
Ce(IV)-doped iron oxide & 60.4 & 45 \\
Laterite soil & 0.055 & 46 \\
Granularferric hydroxide (GFH) & 10.3 & 47 \\
Magnetite & 10 & 48 \\
HA & 526 & Present Study \\
\hline
\end{tabular}


Effect of mass of adsorbent on As(V) removal

The effect of $\mathrm{HA}$ dosage on $\mathrm{As}(\mathrm{V})$ removal was analyzed by varying the dosage of $\mathrm{HA}$ and the result is shown in Fig. 4. It was observed that the removal efficiency increases with the increase in $\mathrm{HA}$ dosage. This reveals that the instantaneous and

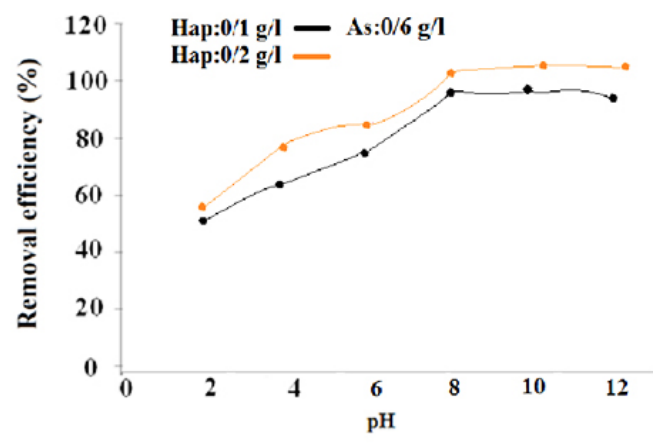

Fig.1: Effect of pH on removal of $A s(V)$ ions with concentration of $0 / 6 \mathrm{~g} / \mathrm{LAs}$

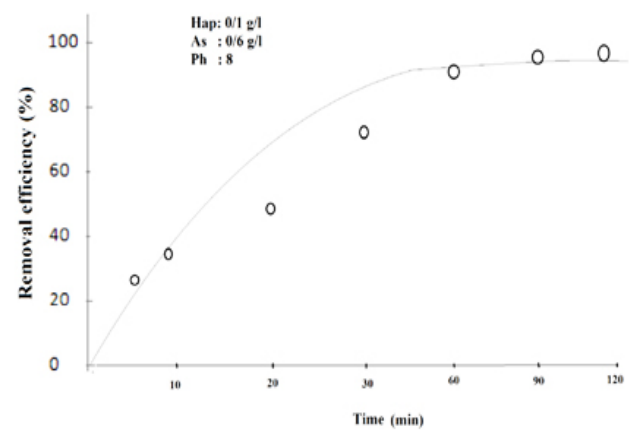

Fig.3: Effect of time on removal of $\mathrm{As}(\mathrm{V})$ ions with $\mathrm{pH}=8$

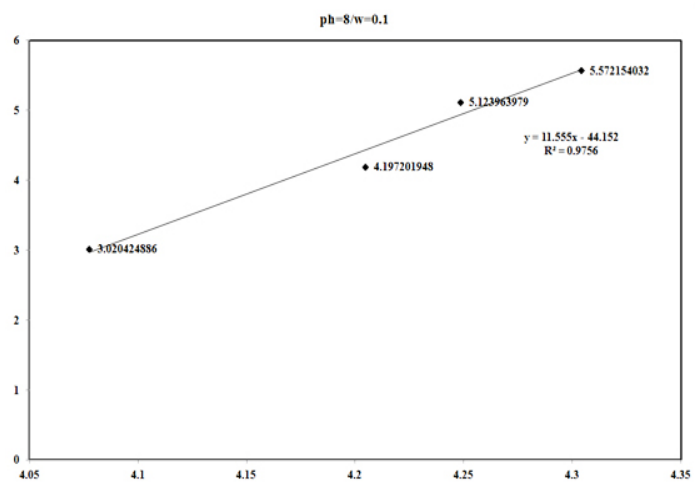

Fig.5: freundlich Isotherm plots for sorption of As (V) by HA equilibrium sorption capacities of $A s(V)$ are functions of the HA dosage

\section{Adsorption isotherms}

Equilibrium isotherm is described by a sorption isotherm, characterized by certain constants

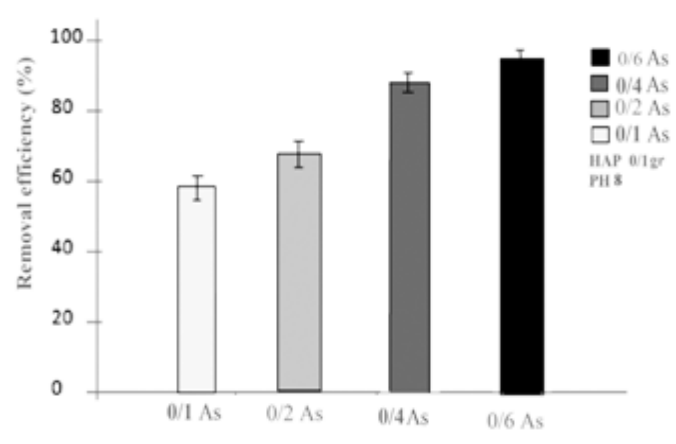

Fig.2: Effect of As on removal of $\mathrm{As}(\mathrm{V})$ ions with $\mathrm{pH}=8$

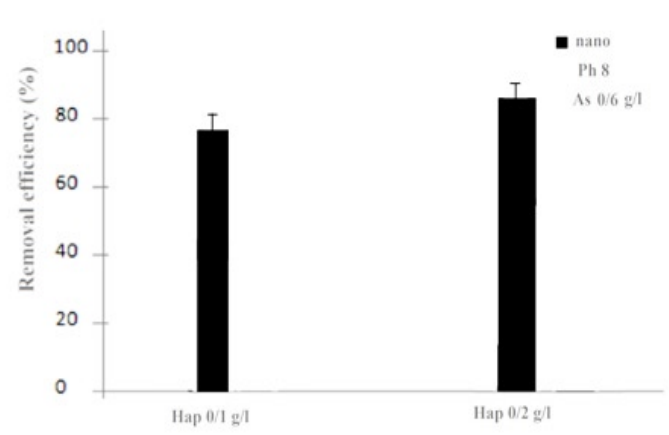

Fig. 4: Effect of dosage on removal of $A s(V)$ ions with $\mathrm{pH}=8$ and $\mathrm{As}=0 / 6 \mathrm{~g} / \mathrm{l}$

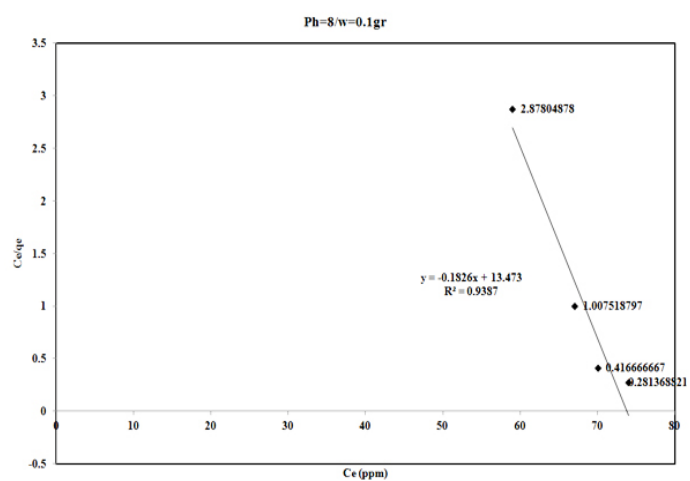

Fig.6: longmuir Isotherm plots for sorption of As (V) by HA 
whose values express the surface properties and affinity of the sorbent sorption equilibrium is established when the concentration of sorbentin the bulk solution is in dynamic balance with that at the sorbent interface (Oladoja et al.,2008). The adsorption isotherm study is carried out on wellknown isotherms such as Langmuir Langmuir $., 1915)$.

$$
\frac{1}{x / m}=\frac{1}{q_{\max }}+\frac{1}{q_{\max }} \frac{1}{b c_{e}}
$$

Where $b$ is the constant that increases with increasing molecular size, $\mathrm{q}_{\max }$ is the amount adsorbed to form a complete monolayer on the surface $(\mathrm{mg} / \mathrm{g}), X$ is weight of substance adsorbed (mg), $\mathrm{M}$ is weight of adsorbent $(\mathrm{g})$, and $\mathrm{Ce}$ is the concentration remaining in solution $(\mathrm{mg} / \mathrm{L})$. The

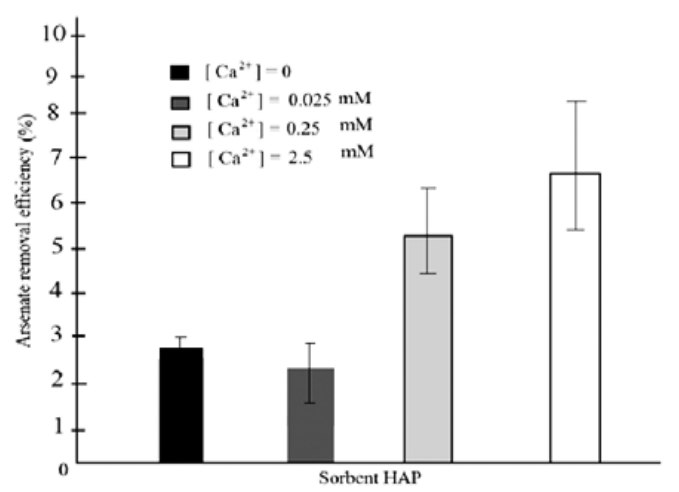

Fig.7: Metal disappearance for removal of $\mathrm{As}(\mathrm{V})$ by HAp

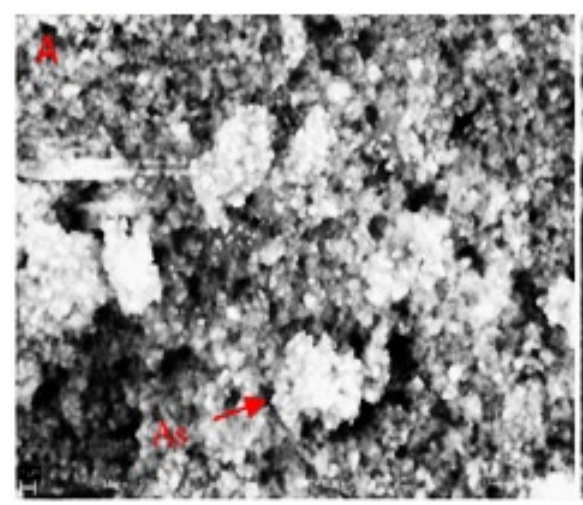

Fig.8: SEM image of adsorbed As by Hydroxyapatite nanoparticles in optimum condition: As : 0/1g/L, HAp : 0/6g/L and pH: 12) at different magnifications A) $5000 \mathrm{X}, \mathrm{B}) 15000 \mathrm{X}$ essential features of the Langmuir isotherm may be expressed in terms of equilibrium parameter $R L$, which is a dimensionless constant referred to as separation factor or equilibrium parameter (Weber and Chakkravorti, 1974).

$$
R L=\frac{1}{1+b c_{\mathrm{O}}}
$$

The value of $R L$ indicates the type of the isotherm to be either unfavorable $(R L[1])$, linear $(R L$ $=1$ ), favorable $(0 \backslash R L \backslash 1)$ or irreversible $(R L=0)$. The Freundlich isotherm is expressed as (Freundlich, 1906) .

$$
l n q_{e}=l n k_{f}+\frac{1}{n} \times l n c_{e}
$$

Where $K_{f}$ and $n$ are the constants depending on temperature An isotherm plot for sorption of As (V) by HAp-nanois shown in Fig 5 and 6 The diagram indicates that the Freundlich isotherm is favorable for removal of As (V) by HAp-nano. The value of Ralso indicates that Langmuir isotherm is favorable. It can be concluded that Freundlich isotherm is the best fit langmuir isotherms. The adsorption capacity of HAp-nanofor As (V) adsorption is compared with other adsorbents (Table 3 ). The value of As (V) uptake by HApnanofound inthis work is significantly higher than that of other adsorbents.

Three types of reactions may control As(V) immobilization by HAp-nano: surface adsorption, cation substitution orprecipitation. The first mechanism is the adsorption of $A s(V)$ ions on the HAp-nanosurfaces and following ion exchange

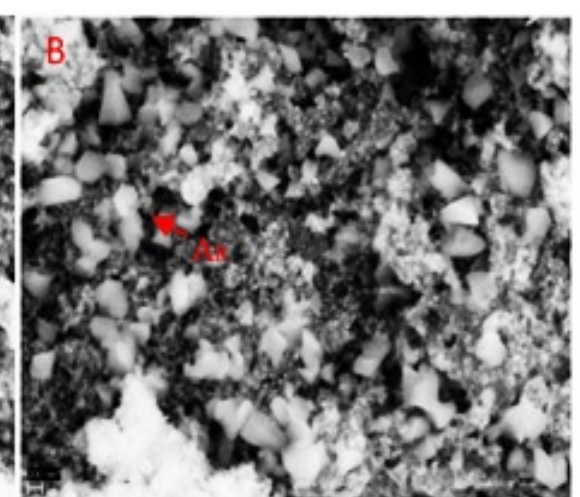


reaction between $\mathrm{As}(\mathrm{V})$ ions adsorbed and $\mathrm{Ca}$ ions of HAp-nano(Suzuki et al.,1984). This ion exchange reaction mechanism (Ma et al.,1994) is expressed as:

$$
\begin{gathered}
\mathrm{Ca}_{10}\left(\mathrm{PO}_{4}\right)_{6}(\mathrm{OH})_{2}+\mathrm{X} \mathrm{As}^{5+} \leftrightarrow \mathrm{XCa}^{2+}+\mathrm{Ca}_{10 \cdot x} \mathrm{Asx}\left(\mathrm{PO}_{4}\right)_{6}(\mathrm{OH})_{2} \\
\mathrm{Ca}_{10}\left(\mathrm{PO}_{4}\right)_{6}(\mathrm{OH})_{2}+14 \mathrm{H}^{2+} \leftrightarrow 10 \mathrm{Ca}^{2+}+6 \mathrm{H}_{2} \mathrm{OPO}_{4}^{-}+2 \mathrm{H}_{2} \mathrm{O}
\end{gathered}
$$

(Dissolution)

Showed that HAp-nano dissolution and hydroxypyromorphite (HP) precipitation were the main mechanisms for As(V) immobilization by HAp-nanoin the absence of other metals. These chemical reactions can bedescribed as follows:

$$
\begin{array}{r}
\mathrm{Ca}_{10}\left(\mathrm{PO}_{4}\right)_{6}(\mathrm{OH})_{2}+14 \mathrm{H}^{2+} \leftrightarrow 10 \mathrm{Ca}^{2+}+6 \mathrm{H}_{2} \mathrm{O} \mathrm{PO}{ }_{4}^{-}+2 \mathrm{H}_{2} \mathrm{O} \\
\text { (Dissolution) } \\
10 \mathrm{As}^{5+}+6 \mathrm{H}_{2} \mathrm{O} \mathrm{PO}_{4}^{-}+2 \mathrm{H}_{2} \mathrm{O} \leftrightarrow 14 \mathrm{H}^{2+}+\mathrm{As}_{10}\left(\mathrm{PO}_{4}\right)_{6}(\mathrm{OH})_{2} \\
\text { (Percipitation) }
\end{array}
$$

Information about the sorption mechanisms have been inferred by the values of molar ratios (Qs) of cations bound by HAp-nanoto $\mathrm{Ca}$ desorbed from HAp-nano (Aklil et al., 2004). Fig 7 presents the effect of calcium concentration on arsenate removal by HAp-nano. For all sorbents tested, increasing calcium level appeared to assist arsenate sorption. When calcium concentration increased from 0 to $2.5 \mathrm{mM}$, the arsenate removal efficiency increased from $2.4 \%$ to $5.4 \%$ by using HAp-nano. The calcium effects on arsenate sorption to HAp-nanoare to be due to two reasons. First, according to increasing calcium concentration in water can inhibit HAp-nano, which can inhibit arsenate sorption to the sorbents. Second, $\mathrm{Ca}^{2+}$ in water can complex with phosphate on HAp-nano surface, resulting in an increase of sorption sites and subsequently an increase of arsenate sorption (Czerniczyniec et al.,2007; Sneddon et al.,2005). SEM image of absorb $A s(\mathrm{~V})$ by nanoparticles of HAp-nanoshown in figure8.

\section{CONCLUSION}

The result shows that hydroxyapatite nanoparticle (HAp-nano) is a powerful adsorbent for removing $\mathrm{As}(\mathrm{V})$ from aqueous solution. The optimum dose of HAp-nanofor As $(\mathrm{V})$ removal is found to be $0.2 \mathrm{~g} / \mathrm{L}$ with the removal efficiency of 88 $\%$. Freundlich isotherm had best fit than Langmuir, for experimental data. The adsorption capacity of HAp-nano was found to be $526 \mathrm{mg} / \mathrm{g}$ HAp-nano dissolution and hydroxy pyromorphite precipitation were the main mechanisms for $\mathrm{As}(\mathrm{V})$ immobilization by HAp-nano.

\section{ACKNOWLEDGMENTS}

The authors gratefully acknowledge financial assistance of Iran nanotechnology initiative council.

\section{REFERENCES}

1. Abdel-Ghani N.T., Hefny M. and El-Chagbaby G.A.F. 'Removal of lead from aqueous solution using low cost abundantly available adsorbents' Int. J. Environ. Sci. Tech., 1:67-73 v.

2. Aklil M., Mouflih M. and Sebti S. 'Removal of heavy metal ions from water by using calcined phosphate as a new adsorbent' J Hazard Mater., 112: 183-190 (2004).

3. Bissen, M., Frimmel, F.H. 'Arsenic- a review. Part I. Occurance, toxicity, speciation, mobility' Acta Hydrochim. Hydrobiol., 2: 9-18 (2003).

4. Boddu V.M., Abburi K., Talbott J.L., Smith E.D. and Haasch R. 'Removal of arsenic (III) and arsenic (V) from aqueous medium using chitosan-coated biosorbent' Water Res., 3: 633- 642 (2008).
5. Burkel, R.S. and Stoll, R.C." Naturally occurring arsenic in sandstone aquifer water supply wells of North Eastern Wisconsin, Ground Water Monit' Remediation., 2: 114 121 (1999).

6. Chmielewská, E., Sabová, L. and Jesenák, $\mathrm{K}$. 'Study of adsorption phenomena ongoing onto clinoptilolite with the immobilized interfaces'J. Therm. Anal. Calorim., 2: 567 571 (2008).

7. Cernansky S., Urík M., Ševc J. and Hiller E. 'Biosorption of arsenic and cadmium from aqueous solutions' Afr. J. Biotechnol., 16: 1932- 1934 (2007).

8. Czerniczyniec M., Farias S. and Magallanes J. 'Arsenic(V) adsorption onto biogenic hydroxyapatite: solution composition effects' 
Water Air Soil Pollut., 180: 75-82 (2007).

9. Daus, B., Wennrich, R. and Weiss, H. 'Sorption materials for arsenic removal from water: A comparative study' Water Res., 12: 2948-2954 (2004).

10. DeMarco, M.J., SenGupta, A.K. and Greenleaf, J.E. 'Arsenic removal using a polymeric/ inorganic hybrid sorbent' Water Res., 1: 164176 (2003).

11. Eblin, K.E., Bowen, M.E., Cromey, D.W. and Bredfeldt T.G. 'Arsenite and monomethylarsonous acid generate oxidative stress response in human bladder cell culture' Toxicol. Appl. Pharm., 1: 7- 14 (2006).

12. Elliott J.C. 'Structure and Chemistry of the Apatite's and Other Calcium Orthophosphates' Elsevier, Amsterdam, 12: 371 (1994).

13. Freundlich H. 'Adsorption in solution' $Z$ Phys Chem., 57: 384- 470 (1906).

14. Gupta V.K., Agarwal S. and Saleh T.A. 'Synthesis and characterization of aluminacoated carbon nanotubes and their application for lead removal' J Hazard Mater., 185: 17-23 (2011).

15. Hiller E., Veselská V. and Majzlan J. 'Arsenic mobility in stream sediments and impoundment material as evaluated by column and batch experiments' J. Hydrol. Hydromech., 4: 223-235 (2007).

16. Hughes, M.F. 'Arsenic toxicity and potential mechanisms of action' Toxicol. Lett., 1: 1-16 (2002).

17. Jain, C.K. and Ali I. 'Arsenic occurrence, toxicity and speciation techniques' Water Res., 1: 4304-4312 (2000).

18. Kannan N, Karrupasamy K. Low cost adsorbents for the removal of phenyl acetic acid from aqueous solution. Indian $J$ Environ Protect, 18(9): 683-690 (1998).

19. Kiping, M.D., Lenihan, J, Fletcher, W.W. 'Arsenic, the Chemical Environment' Environment and Man., 6: 93-110 (1997).

20. Krestou A., Xenidis A. and Panias D. 'Mechanism of aqueous uranium(VI) uptake by a natural zeolite' Tuff. Miner. Eng., 17: 373-381 (2004).

21. Langmuir I. 'Chemical reactions at low pressures' J Am Chem Soc ., 27: 1139-1143 (1915).

22. Lin T. and Wu J. 'Adsorption of arsenite and arsenate within activated alumina grains: Equilibrium and kinetics' Water Res., 8: 20492057 (2001).

23. Loukidou M.X., Matis K.A., Zouboulis A.I. and Liakopoulou- Kyriakido M. 'Removal of as (V) from wastewaters by chemically modified fungal biomass' Water Res., 18: 4544- 4552 (2003).

24. Ma Q.Y., Traina S.J., Logan T.J. and Ryan J. ' Effect of aqueous $\mathrm{Al}, \mathrm{Cd}, \mathrm{Cu}, \mathrm{Fe}(\mathrm{II}), \mathrm{Ni}$, and Zn on $\mathrm{Pb}$ (II) immobilization by hydroxyapatite' Environ Sci Technol., 28: 1219-1228 (1994).

25. Maji S.K., Pal M., Pal T. and Adak A. 'Adsorption thermodynamic of As on laterite soil'J. Surf. Sci. Technol., 22: 161- 176 (2007).

26. Malakootian M., Nouri J. and Hossaini $\mathrm{H}$. 'Removal of heavy metals from paint industries wastewater using Leca as an available adsorbent' Int. J. Environ. Sci. Tech., 2: 183- 190 (2009).

27. Mittal A, Mittal J, Malviya A, Gupta VK. Removal and recovery of Chrysoidine $Y$ from aqueous solutions by waste materials. J Colloid Interf Sci, 344:497-507(2010).

28. Mayo J.T., Yavuz C., Yean S., Cong L., Shipley H., Yu W., et al. 'The effect of nanocrystalline magnetite size on arsenic removal' Sci. Technol. Adv. Mater., 8: 71- 75(2007).

29. Mohan D and Pittman C. 'Arsenic removal from water/wastewater using adsorbents-a critical review' J. Hazard. Mater., 142: 1-53 (2007).

30. Montazeri, N., Jahandideh, R., and Biazar, E. 'Synthesis of fluorapatite-hydroxyapatite nanoparticles and toxicity investigations' Int.J.Nanomed, 6: 197-201 (2011).

31. Murugesan G.S., Sathishkumar M. and Swaminathan K. 'Arsenic removal from groundwater by pretreated waste tea fungal biomass' Bioresource Technol., 3: 483- 487 (2006).

32. Ng, J.G.C., Howe, A., Hughes, P., Kenyon, M., and et al. 'Environmenal health criteria for arsenic and arsenic' world Health Organisation., 224: 508-512 (2001).

33. Ng, J.C., Wang, J. and Shraim, A.A. 'Global health problem caused by arsenic from natural sources' Chemosphere., 9: 1353-1359 (2003). 
34. Oladoja N.A., Aboluwoye C.O., Oladimeji Y.B. 'Kinetics and isotherm studies on methylene blue adsorption onto ground palm kernel coat' Turkish J Eng Env Sci., 32: 303- 312 (2008).

35. Omar $\mathrm{W}$ and $\mathrm{Al}-$ Itawi $\mathrm{H}$. 'Removal of $\mathrm{Pb}+2$ Ions from Aqueous Solutions by Adsorption on Kaolinite Clay' A. J. of Appl.Sci., 7: 498-502 (2003).

36. Paritam K.D., Ray A.K., Sharma V.K and Millero F.J. 'Adsorption of arsenate and arsenite on titanium dioxide suspensions' J. Colloid Interface Sci., 278: 270-275 (2004).

37. Penrose, W.R. 'Arsenic in the marine and aquatic environments. Analysaism occurrence and significance' Crit. Rev. Environ Contr., 1: 465-482 (2009).

38. Rahaman M.S., Basu A. and Islam M.R. 'The removal of As (III) and As (V) from aqueous solutions by waste materials' Bioresource Technol., 8: 2815- 2823 (2008).

39. Ramesh S.T., Rameshbabu N., Gandhimathi R., Nidheesh P.V. and Srikanth Kumar M., Kinetics and equilibrium studies for the removal of heavy metals in both single and binary systems using hydroxyapatite, Appl Water Sci., 2: 187- 197( 2012).

40. Sato Y., Kang M., Kamei T. and Magara Y. 'Performance of nanofiltration for arsenic removal' Water Res., 13: 3371- 3377 (2002).

41. Seki H., Suzuki A. and Maruyama H. 'Biosorption of chromium (VI) and arsenic (V) onto methylated yeast biomass' J. Colloid. Interf. Sci., 2: 261- 266 (2005).

42. Smedley, P.L., Nicolli, H.B., Macdonald, D.M.J., Barros, A.J. and Tullio, J.O. 'Hydrogeochemistry of arsenic and other inorganic constituents in groundwaters from La Pampa, Argentina' Appl. Geochem., 3: 259-284 (2002).

43. Sneddon I., Garelick H. and Valsami-Jones E. 'An investigation into arsenic(V) removal from aquesous solutions by hydroxylapatite and bone-char' Mineral. Mag., 69: 769- 780 (2005).

44. Song S., Lopez-Valdivieso A.N., HernandesCampos D.J., Peng C., Monroy- Fernandez M.G. and Razo-Soto I. 'Arsenic removal from high-arsenic water by enhanced coagulation with ferric ions and coarse calcite' Water Res., 2: 364-372 (2006).

45. Suzuki T., Ishigaki K. and Miyake M. 'Synthetic hydroxyapatites as inorganic cation exchangers exchange characteristics of $\mathrm{Pb}(\mathrm{II})$ ions' J Chem Soc Faraday Trans., 80: 3157- 3165 (1984).

46. Takeuchi $\mathrm{Y}$ and Arai $\mathrm{H}$. 'Removal of coexisting $\mathrm{Pb}^{2+}, \mathrm{Cu}^{2+}, \mathrm{Cd}^{2+}$ ions from water by addition of hydroxyapatite powder' J.Chem. Eng. Jpn., 1: 75-80 (1990).

47. Tanaka H., Futaoka M., Hino R., Kandori K. and Ishikawa T. 'Structure of synthetic calcium hydroxyapatite particles modified with pyrophosphoric acid' J. Colloid Interf. Sci., 2: 283- 609 (2005).

48. Thirunavukkarasu O.S., Viraraghavan T. and Subramanian K.S. 'Arsenic removal from drinking water using granular ferric hydroxide' Water S A., 2: 1-5 (2003).

49. Valsami-Jones E, Ragnarsdottir K., Putnis A., Bosbach D., Kemp A. and Gressey G., 'The dissolution of apatite in the presence of aqueous metal cations at $\mathrm{pH}$ 2-7' Chem. Geol., 151: 215- 233 (1998).

50. Vega E.D., Pedregosa J.C. and Narda G.E. 'Interaction of oxovanadium(IV) with crystalline calcium hydroxyapatite: surface mechanism with no structural modification' J. Phys. Chem.Solids., 60: 759-766 (1999).

51. Weber T.W and Chakkravorti R.K. 'Pore and solid diffusion models for fixed bed adsorbers' AIChE J., 20: 228- 238 (1974).

52. Zhang Y., Yang M. and Huang X. 'Arsenic(V) removal with a $\mathrm{Ce}(\mathrm{IV})$-doped iron oxide adsorbent'Chemosphere., 51: 945-952 (2003). 